\title{
Koroner Arter Hastalığı Şiddeti ve Trombosit Agregasyonu
}

\section{Coronary Artery Disease Severity and Platelet Aggregation}

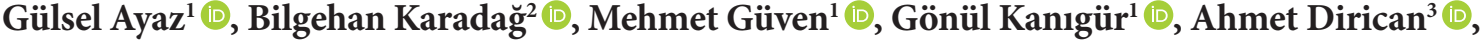 \\ Barış İlerigelen ${ }^{2}$ (i), Turgut Ulutin ${ }^{1}$ (i)
}

1 İstanbul Üniversitesi-Cerrahpaşa, Cerrahpaşa Tip Fakültesi, Temel Tip Bilimleri Bölümü, Tibbi Biyoloji Anabilim Dalı, İstanbul, Türkiye

2 İstanbul Üniversitesi-Cerrahpașa, Cerrahpașa Tip Fakültesi, Dahili Tıp Bilimleri Bölümü, Kardiyoloji Anabilim Dal, İstanbul, Türkiye

3 İstanbul Üniversitesi-Cerrahpaşa, Cerrahpaşa Tip Fakültesi, Temel Tip Bilimleri Bölümü, Biyoistatistik Anabilim Dalı, İstanbul, Türkiye

ORCID: G.A. 0000-0003-3085-232X;

B.K. 0000-0002-1361-5229;

M.G. 0000-0002-8749-1708

G.K. 0000-0001-9029-1910;

A.D. 0000-0001-8454-4547;

B.İ. 0000-0002-2039-8090;

T.U. 0000-0002-0406-1746

Sorumlu yazar/Corresponding author: Gülsel Ayaz

İstanbul Üniversitesi-Cerrahpaşa, Cerrahpaşa Tıp Fakültesi, Temel Tıp Bilimleri Bölümü, Tıbbi Biyoloji Anabilim Dalı, İstanbul, Türkiye E-mail: gulsel.ayaz@gmail.com

Geliş tarihi/Submitted: 21.12.2020 İlk revizyon/First Revision Received: 04.01.2021 Son Revizyon/Last Revision Received: 16.01.2021 Kabul tarihi/Accepted: 20.01.2021

Atıf/Citation: Ayaz G, Karadag B, Guven B, Kanigur G, Dirican A, Ilerigelen B, et al. Coronary artery disease severity and platelet aggregation. Sağlık Bilimlerinde İleri Araştırmalar Dergisi 2021, 4(1): 13-19.

https://doi.org/10.26650/JARHS2021-843387
ÖZ

Amaç: Koroner Arter Hastalığı (KAH), çoğunlukla ateroskleroz sebebiyle kalbi besleyen damarların daralması veya tıkanması ile ortaya çıkmaktadır. Ateroskleroz patogenezinde aterosklerotik risk faktörlerinin yanı sıra inflamasyon, endotel disfonksiyonu ve buna bağl olarak trombosit aktivasyonu sıklıkla görülmektedir. KAH'da trombosit fonksiyonlarını araştıran çalışmalar olmasına rağmen, hastalık şiddeti ile trombosit aktivasyonu arasındaki ilişkiye dair çalışmalar kısıtlıdır. Bu çalışmada, tıkalı damar sayısı ile trombosit fonksiyonları arasındaki ilişkiyi araştırmayı amaçladık.

Gereç ve Yöntem: Koroner anjiyografi ile damar tıkanıklığı tespit edilen KAH olguları, hastalık şiddetine göre 3 alt gruba ayrıldı. Işık geçirgenliği agregometri (LTA) yöntemi ile KAH ve sağlıklı kontrollere adenozindifosfat (ADP) uyaranı ile trombosit agregasyon testi uygulandı. Trombosit agregasyon testinin sonuçları, agregasyon kurbu eğimi ohm $(' \Omega)$ ve agregasyonun maksimum kapsamı yüzde (\%) Amplitüd olarak hesaplandı.

Bulgular: Trombosit agregasyon testinde KAH agregasyon eğim değerleri $\left(116,90 \pm 28,21^{\mathrm{a}}\right)$ kontrole göre $\left(113,90 \pm 35,16^{\mathrm{a}}\right)$ yüksek olmasına rağmen aralarında istatistiksel olarak bir farklılık yoktur $\left(\mathrm{p}=0,526^{\mathrm{a}}\right)$. (\%) Amplitüd değerleri kontrol grubunda $\left(74,73 \pm 30,71^{\mathrm{a}}\right)$, KAH grubuna göre $\left(66,51 \pm 25,18^{\mathrm{a}}\right)$ yüksek olmasına rağmen aralarında istatistiksel olarak anlamlılık bulunmamaktadır $\left(\mathrm{p}=0,056^{\mathrm{a}}\right)$. KAH alt gruplarının agregasyon eğim $(' \Omega)$ ve (\%) Amplitüd değerleri arasında istatistiksel olarak bir fark saptanmamıştır (Eğim (' $\Omega$ ) p=0,461 b, (\%) Amplitüd $\mathrm{p}=0,140^{\mathrm{c}}$ ).

Sonuç: KAH olgularında, ADP aracılı agregasyon testi sonuçlarını hastalık şiddetine göre değerlendirdiğimiz bu çalışmada, damar tıkanıklığı sayısı ile agregasyon testi sonuçları arasında istatistiksel olarak anlamlı bir ilişki saptanmamıştır.

Anahtar Kelimeler: Trombosit, Koroner Arter Hastalığı, ADP, Trombosit agregasyonu

\section{ABSTRACT}

Objective: Coronary Artery Disease (CAD) is caused by the narrowing or occlusion of the vessels feeding the heart, mostly due to atherosclerosis. In the pathogenesis of atherosclerosis, besides atherosclerotic risk factors, inflammation, endothelial dysfunction and related platelet activation are frequently observed. While there are studies investigating platelet functions in CAD, studies on the relationship between disease severity and platelet activation are limited. In this study, we aimed to investigate the relationship between the number of occluded vessels and platelet functions.

Materials and Methods: The cases of CAD with vascular occlusion detected by coronary angiography were divided into 3 subgroups according to disease severity. The platelet aggregation test with Adenosindiphosphate (ADP) stimulation was applied to the CAD and healthy controls with the Light Transmittance Aggregometry (LTA) method. The results of that test were calculated as aggregation curve slope and \% Amplitude.

Results: In the platelet aggregation test, although the CAD aggregation slope values $\left(116.90 \pm 28.21^{a}\right)$ were higher than the control $\left(113.90 \pm 35.16^{a}\right)$ there was no statistically significant difference $\left(\mathrm{p}=0.526^{\mathrm{a}}\right)$. Although $\%$ Amplitude values were higher in the control group $\left(74.73 \pm 30.71^{\mathrm{a}}\right)$ compared to the CAD group $\left(66.51 \pm 25.18^{\mathrm{a}}\right)$ there was no statistical significance between them $\left(\mathrm{p}=0.056^{\mathrm{a}}\right)$. There was no statistically significant difference between aggregation slope and \% Amplitude values of the CAD subgroups (Slope $\mathrm{p}=0.461^{\mathrm{b}}, \%$ Amplitude $\mathrm{p}=0.140^{\mathrm{c}}$ ). Conclusion: In this study, in which we evaluated the results of ADP-induced aggregation tests according to the severity of the disease in CAD cases, no statistically significant relationship was found between the number of vascular occlusion and the results of the aggregation test. Keywords: Platelet, Coronary Artery Disease, ADP, Platelet aggregation 


\section{GİRIŞ}

Koroner arterler kalbi besleyen damarlardır. Koroner Arter Hastalığı (KAH) bu damarların çoğunlukla ateroskleroz sebebiyle daralması veya tıkanması sonucu ortaya çıkar. Otuz beş yaşın üstündeki ölümlerin yaklaşık üçte birine sebep olan KAH, tüm dünyada görülen morbidite ve mortalitenin başlıca nedenidir $(1,2)$. KAH progresyonuna sebep olan temel patofizyolojik mekanizmalar incelendiğinde, hastalığın klinik olarak ortaya çımadan önce ateroskleroza zemin hazırlayan süreçlerin yıllar öncesinden gelişip ilerlediği gözlenmiş̧ir $(3,4)$. Ateroskleroz gibi vasküler endotelyal sistemle direkt ilişkili patolojik durumlarda, trombositlerin bu sürece aktif olarak katıldığını gösteren çok sayıda araştırma mevcuttur (5-7).

Kemik iliğinde ve akciğerlerde megakaryositler tarafından üretilen trombositler, başlica tromboz ve hemostaz mekanizmalarında rol alan, 4-7 mikron çapında anüklear hücrelerdir $(8,9)$. Ortalama ömürleri 7-10 gün olan trombositler, retiküloendotelyal sistem hücreleri tarafından dolaşımdan uzaklaştırılıp dalakta yıkılırlar. Endotel hücreleri vasküler sistemde yer alırlar ve damarların iç yüzeyini kaplarlar. Normal şartlar altında endotel, trombositler, koagulasyon faktörleri hemostatik sistemi oluşturarak, dolaşımda bir denge içinde çalışırlar (10). Trombositler depoladıkları, ürettikleri ve salgıladıkları aracı moleküller ile vasküler sistemle yoğun etkileşim içinde bulunur (11, 12). Damar yapısında herhangi bir değişikliğin meydana gelmesi, örneğin endotel bütünlügünün bozulması, endotel disfonksiyon veya hasarı, aterosklerotik plak yırtılması veya çeşitli enflamatuvar durumlar, trombositlerin aktivasyonuna yol açarlar (13). Aktifleşen trombositler yüzey reseptörleri ile hasarlı damar bölgesine tutunup, salgıladıkları mediyatörler aracıl1ğıyla hasara yanıt oluştururlar. Endotel hasarına bağlı olarak subendotelyal bölgedeki ekstrasellüler matriks (ECM) bileşenleri açığa çıkar. ECM bileşenlerinden kollajen ve hasarlı endotel yüzeyinde açığa çıkan von Willebrand faktör (vWF), trombositlerin yüzey reseptörleri aracılığıyla endotele yapışması için tutunma bölgelerini oluşturur (14).

Aktifleşen trombosit üç ana fonksiyon gösterir. Bunlar sirasıyla adezyon, sekresyon ve agregasyondur.
Trombosit hasarlı endotele yapıştıktan sonra yoğun kanaliküler sistemi aracılığıyla granül içeriğini dışarı boşaltır (15). Yoğun granül sekresyonu ile bir yandan diğer trombositler hasarlı bölgeye çağrılırken diğer yandan otokrin pozitif feedback yol ile trombositler kendi kendilerini aktive ederler. Bir sonraki aşamada diğer trombositlerin hasarlı bölgeye toplanması ve üst üste kümelenmesi ile agregasyon fazına geçilir. Fizyolojik şartlar altında agregasyon fazından sonra oluşan trombus fibrinolitik sistem tarafından eritilir ve pihtı uzaklaştırılır (16). Patolojik durumlarda ise trombus fibrinolitik sistem tarafından eritilip uzaklaştırılamaz ve bu süreç damar tıkanıklığı, hipoperfüzyona bağ 1 kan akımının yavaşlaması iskemi gibi süreçlerin önünü açabilir. Trombositlerin, vasküler sistemden etkilenen hastalıklarla ilgili örneğin hipertansiyon, preeklemsi, kardiyovasküler hastalıklar (KVH), metabolik sendrom, serebrovasküler hastalıklar, serebral amiloid anjiopati (CAA), diyabet, inflamasyon, astım, kanser, ateroskleroz gibi patolojik süreçlerdeki rollerinin yanı sıra, fizyolojik süreçlerde ve yaşlanma ile ilgili etki mekanizmalarını incelemek üzere birçok araştırma yapılmıştır (17-20)

Özellikle KVH'larda trombosit fonksiyonlarının hastalıkla olan ilişkisinin araştırılmasına yönelik yapılan çalışmalarda, trombositlere ait hücre içi sinyal yolakları ve moleküler mekanizmaların aydınlatılması ile trombositlerin aktif olarak rol aldığı fizyolojik ve patolojik süreçlerin anlaşılması sağlanmıştır. Tüm bu çalışmalar trombosit fonksiyonlarının düzenlenerek yeni tedavi yaklaşımlarının geliştirilmesinde son derece önemli olmuştur (21).

Klinik değerlendirmelerde trombosit fonksiyonlarının kullanımı oldukça yaygındır. Bu bağlamda in vitro trombosit fonksiyon testlerinden biri olan ve altın standart olarak kabul edilen Işık Geçirgenliği Agregometresi (Light Transmittance Aggregometry, LTA, türbidimetrik veya optik agregometri), ilk defa 1962'de Gustav Victor Rudolf Born tarafından dünyaya duyurulmuştur (22). Bu buluş yıllar içinde temel metodolojisi değişmeden yerini korumuştur (23). LTẢnın temel çalışma prensibine bakıldığında, trombositten zengin plazmaya (Platelet rich plasma, PRP) geniş bir agonist paneli eklenerek trombosit aktivas- 
yonunun ve agregasyonunun ölçülmesi esasına dayanır. PRP örneğine, farklı trombosit aktivasyon yollarını uyarmak için çeşitli agonistler (ADP, epinefrin, araşidonik asit, kollajen, trombin ve ristosetin) eklenir ve trombosit fonksiyonunun özellikleri hakkında bilgi elde edilir (24).

Bizler bu çalışmamızda koroner anjiyografi ile çeşitli düzeylerde damar tıkanıklı̆̆ 1 olduğu saptanan KAH olguları ile anjiyografi sonrası herhangi bir damar tıkanıklığı olmayan sağliklı kontrol grubunda trombosit fonksiyonlarını altın standart olarak kabul edilen LTA yöntemi ile lumi agregometre cihazında trombosit agregasyonunu tespit ettik ve hastalık şiddetine göre ayırdığımız alt gruplarda trombosit fonksiyonlarının ne şekilde değiştiğini araştırdık. Yaptığımız literatür taramasında KAH'da trombosit fonksiyonlarını çeşitli yöntemlerle araştıran birçok çalışma olmasına rağmen, hastalık şiddetine göre alt gruplarda trombosit agregasyonunun ne şekilde değiştiğini gösteren az sayıda çalışmaya rastladık. Çalışmamızın literatürdeki bu boşluğu dolduracağını ve bundan sonraki çalışmalara ışık tutacağını düşünüyoruz.

\section{GEREÇ ve YÖNTEM}

Bu çalışma, Eylül 2010 ile Ocak 2011 tarihleri arasında, KAH şüphesi ile kardiyoloji polikliniğine başvuran ve kardiyak kateterizasyon laboratuvarında rutin tanı amaçlı koroner anjiyografi (CAG) yapılan, toplam 198 ardışık bireyden (124 erkek, 74 kadın) oluşmaktadır. Çalışma kapsamında Cerrahpaşa Tip Fakültesi Klinik Araştırmalar Etik Kurulu’ndan etik kurul onayı alınmıştır. Katılımcılar gönüllü onam formu ile bilgilendirilmiş ve yazılı olarak onayları alınmıștır.

Çalışma grubunu oluşturan 198 denek, koroner arter hastalığının varlığına veya yokluğuna göre 2 gruba ayrıldı. Koroner anjiyografi sonucuna göre normal olan ( $<\% 50$ koroner darlık veya normal koroner arterler) 85 denek (\%45 erkek, \%55 kadın) kontrol grubunu oluştururken, en az 1 koroner arter ve $\geq \% 50$ lümen çapı darlığı olan 113 kişi (\%76 erkekler, \%24 kadın) hasta grubu olarak belirlendi. Trombosit fonksiyon deneyleri için 1/9 oranında \%3.8'lik sodyum sitrat ile karıştırılılan taze femoral arter kanı örnekleri kullanıldı. Alınan kan örnekleri 30 dakika oda sıcaklığında bekletildi. Laboratuvar koşulları altında trombositten zengin plazma (TZP) elde etmek amacı ile sitratlı kan örnekleri 750 RPM'de 15 dakika boyunca oda sicaklığında santrifüj edildi. Santrifüj sonrasinda kan tüplerinin en üst kısmında yer alan TZP pipet yardımı ile toplanıp $1.5 \mathrm{ml}$ 'lik steril ependorf tüplere aktarıldı. Kalan kan örneği 3000 RPM’de 15 dakika santrifüj edilerek trombositten fakir plazma (TFP) elde edildi. Trombosit fonksiyon deneyleri, LTA yöntemi ile lumi agregometre cihazında 500 $\mu \mathrm{L}$ TZP için final konsantrasyonu $1 \mu \mathrm{M}$ olan $5 \mu \mathrm{L}$ ADP uyaranı verilerek in vitro koşullar altında gerçekleştirildi. (Chrono-Log 500-CA, 500CA Whole Blood Lumi Aggregometer, CHRONO-LOG CORP. Havertown, PA, USA). Deneylerde her bir örnek için 3 dakika boyunca agregasyon kurbunun oluşması gözlemlendi. Elde edilen verilere göre agregasyon kurbu eğimi ohm $(\Omega)$ ve \% Amplitüd olarak hesaplandi.

\section{İstatistiksel Analiz}

İstatistiksel analizlerde SPSS 17.5 paket program kullanılmıştır. Yorumlamalarda anlamlılık sınırı $p<0,05$ olarak kullanılmıștır. Gruplar arası frekans ve yüzdelerin kıyaslanmasında Ki-kare ve Fisher kesin olasılık testi kullanılmıştır. Normal dağılım gösteren değişken iki grubun ortalamalarının kıyaslaması T testi ile yapılmıştır. İkiden fazla grup ortalamasının kıyaslaması ANOVA kullanılmış, ANOVA'da anlam1 fark gösteren alt grupların ikili kıyaslanmasında "post-hoc Tukey HSD" testi yapılmıştır.

\section{BULGULAR}

Çalışmaya katılan 198 kişinin koroner anjiyografi sonuçları değerlendirildiğinde, denekler koroner arter hastalığının varlığına veya yokluğuna göre başlica 2 ana gruba ayrıldı. Demografik veriler incelediğinde koroner anjiyografisi normal saptanan ve kontrol grubunu oluşturan 85 kişinin \% 45 ’i erkek, \%55’i kadın ve anjiyografi sonucuna göre koroner arter hastalığı bulunan 113 kişiden \%76’sı erkek ,\%24 kadındır (Tablo 1). Kontrol deneklerinin yaşları 31 ile 83 arasinda (ortalama $=59,36 \pm 10,92$ ) ve koroner arter 
hastalığı olan hastaların yaşları 29 ile 85 (ortala$\mathrm{ma}=61,45 \pm 9,71)$ arasında ve her iki grubun yaş ortalamaları dağılımı benzer olup aralarında istatistiksel olarak fark bulunmamıştır $(\mathrm{p}=0,07)$. KAH grubunun \%77'si ( $\mathrm{n}=87$ ) hipertansiyon, \%56's1 ( $\mathrm{n}=63$ ) diyabet, \%65'i $(\mathrm{n}=73)$ sigara içenlerden oluşmaktadır. Kontrol grubunun \%48'i $(\mathrm{n}=41)$ hipertansiyon, \%20 'si ( $\mathrm{n}=17)$ diyabet, \%14'ü $(\mathrm{n}=12)$ sigara içenlerden olumaktadır. Ayrıca hasta ve kontrol örneklerine ait trombosit sayısı, trombosit hacmi, beyaz kan hücresi (WBC) ve hemoglobin (Hgb) değerleri gibi kan parametreleri açısından değerlendirildiğinde gruplar arasında istatistiksel olarak anlamlı bir fark bulunmamıştır (Tablo 1).

Tablo 2'de Toplam KAH hasta grubunda eğim $(\Omega)$ değerleri $116,90 \pm 28,21^{\text {a }}$ iken, kontrol grubunda $113,90 \pm 35,16^{\mathrm{a}}(\Omega)$ olarak tespit edilmiştir $\left(\mathrm{p}=0,526^{\mathrm{a}}\right)$. Hasta ve kontrol gruplarımız arasında istatistiksel olarak bir anlamlılık saptanmamıştır. Tablo 2'deki trombosit agregasyon \% Amplitüd değerleri kontrol

Tablo 1. KAH - Kontrol Gruplarına ait demografik ve llinik bilgiler.

\begin{tabular}{|l|c|c|c|}
\hline & $\begin{array}{c}\text { KAH } \\
(\mathbf{n = 1 1 3 )} \\
\text { Ort } \pm \text { Std }\end{array}$ & $\begin{array}{c}\text { Kontrol } \\
(\mathbf{n = 8 5 )} \\
\text { Ort } \pm \text { Std }\end{array}$ & $\begin{array}{c}\mathbf{p} \\
\text { değeri }\end{array}$ \\
\hline Yaş (Yıl) & $61,45 \pm 9,71$ & $59,36 \pm 10,92$ & $0,07^{\mathrm{a}}$ \\
\hline Yaş aralığ $($ Yıl) & $29-85$ & $31-83$ & \\
\hline Erkek. n $(\%)$ & $86(\% 76)$ & $38(\% 45)$ & $<0,001^{\mathrm{b}}$ \\
\hline Kadın. $\mathrm{n}(\%)$ & $27(\% 24)$ & $47(\% 55)$ & $<0,001^{\mathrm{b}}$ \\
\hline $\begin{array}{l}\text { Trombosit }\left(10^{3} /\right. \\
\mu l)\end{array}$ & $248,69 \pm 82,28$ & $256,6 \pm 53,87$ & $0,482^{\mathrm{a}}$ \\
\hline $\begin{array}{l}\text { Trombosit V } \\
(\mathrm{fL})\end{array}$ & $10,37 \pm 1,12$ & $10,08 \pm 1,55$ & $0,164^{\mathrm{a}}$ \\
\hline WBC $\left(10^{3} / \mu \mathrm{l}\right)$ & $8,06 \pm 2,25$ & $7,70 \pm 2,38$ & $0,334^{\mathrm{a}}$ \\
\hline Hgb $(\mathrm{g} / \mathrm{dL})$ & $13,53 \pm 1,80$ & $13,22 \pm 1,76$ & $0,272^{\mathrm{a}}$ \\
\hline
\end{tabular}

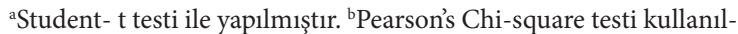
mıştır; (White Blood Cell= WBC, Hemoglobin= Hgb) grubunda $\left(74,73 \pm 30,71^{\mathrm{a}} \Omega\right)$, hasta grubu $\left(66,51 \pm 25,18^{\mathrm{a}}\right.$ $\Omega$ )'na göre daha yüksek bulunmasına rağmen aralarında istatistiksel olarak bir anlamlllık gözlenmemiştir $\left(\mathrm{p}=0,056^{\mathrm{a}}\right)$.

Toplam KAH hastalarını tıkalı damar sayılarına göre alt gruplara ayırıp 1 damar, 2 damar,3 damar tıkanıklığı olan alt grupların eğim değerlerini birbirleri ile kıyaslandığında istatistiksel olarak bir anlamlilık saptanmamıştır ( $\mathrm{p}=0,461^{\mathrm{b}}$ ) (Tablo 2). Yapılan istatistiksel analize göre 1, 2 ve 3 damar tıkalı alt gruplarda \% Amplitüd değerleri kıyaslandığında, alt gruplar arasinda istatistiksel olarak bir farklılık saptanmamıștır $\left(\mathrm{p}=0,140^{c}\right)$ (Tablo 2).

\section{TARTIŞMA}

Trombosit fonksiyonları ve hastalık mekanizmaları arasındaki ilişki sıklıkla merak edilen ve araştırılan konulardan biridir. Başlıca tromboz, hemostaz ve koagulasyon mekanizmalarında yer alan trombositlerin sadece hematolojik hastalıklarda değil aynı zamanda endotel hasarına bağlı gelişen vasküler yanıtta, inflamasyon ve kanser gibi süreçlerde de kritik rol oynadığını gösteren birçok araştırma mevcuttur. Trombosit agregasyon testi, trombosit fonksiyon ve işlev bozukluklarını tespit etmek için yapılan çalışmalarda altın standart olarak kabul edilmektedir ve klinikte yaygın olarak kullanılmaktadır (23). Günümüzde hematolojik hastalıkların yanı sıra endotel disfonksiyon veya hasarın eşlik ettiği durumlarla ilişkili hastalıkların patofizyolojisini incelemek için LTA yöntemi ile trombosit agregasyonunu araştıran çalışmalar bulunmaktadır $(17,18,19,20,21)$.

Preeklemsi hastalığını araştırdığımız bir çalışmada, trombosit fonksiyonlarını LTA agregometri testi ile incelenmiş ve 52 preeklemsi hastası ile 27

Tablo 2. Kontrol ve KAH gruplarında hastalık şiddetine göre Trombosit Agregasyonu Eğim $(\Omega)$, \% amplitüd değerlerinin karşılaștırılması.

\begin{tabular}{|l|c|c|c|c|c|c|}
\hline $\begin{array}{l}\text { Trombosit } \\
\text { agregasyonu }\end{array}$ & $\begin{array}{c}\text { 1 Damar } \\
\text { Ort } \pm \text { Std }(\mathbf{n})\end{array}$ & $\begin{array}{c}\text { 2 Damar } \\
\text { Ort } \pm \text { Std }(\mathbf{n})\end{array}$ & $\begin{array}{c}\text { 3 Damar } \\
\text { Ort } \pm \text { Std }(\mathbf{n})\end{array}$ & $\begin{array}{c}\text { Toplam KAH } \\
\text { Ort } \pm \text { Std }(\mathbf{n})\end{array}$ & $\begin{array}{c}\text { Kontrol } \\
\text { Ort } \pm \text { Std (n) }\end{array}$ & $\begin{array}{c}\text { p } \\
\text { değeri }\end{array}$ \\
\hline EĞİM $(\Omega)$ & $\begin{array}{c}122,80 \pm 29,14^{\mathrm{b}} \\
(\mathrm{n}=40)\end{array}$ & $\begin{array}{c}110,40 \pm 32,26^{\mathrm{b}} \\
(\mathrm{n}=32)\end{array}$ & $\begin{array}{c}113,50 \pm 22,81^{\mathrm{b}} \\
(\mathrm{n}=25)\end{array}$ & $\begin{array}{c}116,90 \pm 28,21^{\mathrm{a}} \\
(\mathrm{n}=97)\end{array}$ & $\begin{array}{c}113,90 \pm 35,16^{\mathrm{a}} \\
(\mathrm{n}=74)\end{array}$ & $0,526^{\mathrm{a}}$ \\
& $\begin{array}{c}67,69 \pm 25,78^{\mathrm{c}} \\
(\mathrm{n}=40)\end{array}$ & $\begin{array}{c}70,98 \pm 25,98^{\mathrm{c}} \\
(\mathrm{n}=32)\end{array}$ & $\begin{array}{c}60,63 \pm 23,90^{\mathrm{c}} \\
(\mathrm{n}=25)\end{array}$ & $\begin{array}{c}66,51 \pm 25,18^{\mathrm{a}} \\
(\mathrm{n}=97)\end{array}$ & $\begin{array}{c}74,73 \pm 30,71^{\mathrm{a}} \\
(\mathrm{n}=74)\end{array}$ & $0,056^{\mathrm{a}}$ \\
\hline
\end{tabular}

Toplam KAH-Kontrol Eğim (' $\Omega$ ) için $p=0,526^{a}$ aStudent- $t$ testi ile yapılmıștır; Toplam KAH-Kontrol \% amplitüd için $p=0,056^{a}$ aStudent-

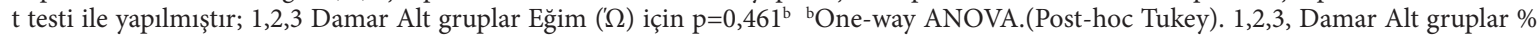
Amplitüd için $\mathrm{p}=0,140^{\mathrm{c}}{ }^{\circ}$ One-way ANOVA.(Post-hoc Tukey). 
sağlıklı bireyde agregasyon sonuçlarını bildirmiştik (17). Çalışmada ADP ile indüklenmiş trombosit agregasyon sonuçlarına göre, eğim değerleri $(\Omega)$ preeklemsi grubunda $66,92 \pm 12,65(\Omega)$ ve kontrol grubunda $66,47 \pm 15,71(\Omega)$ olarak bulunmuştur. Agregasyon \% Amplitüd değerleri ise kontrol grubunda $(84,82 \pm 23,32)$, hasta grubuna $(77,78 \pm 17,61)$ kıyasla daha yüksek olmasına rağmen gruplar arasında istatistiksel olarak anlamlı bir fark görülmemiştir (17). Preeklemsi araştırmasının sonuçlarını, KAH hastalığında yaptığımız bu çalışma ile karşılaştıracak olursak, Toplam KAH hasta grubunda eğim değerleri $116,90 \pm 28,21^{\text {a }}(\Omega)$ iken, kontrol grubunda $113,90 \pm 35,16^{\text {a }}(\Omega)$ olarak tespit edilmiştir. Hasta ve kontrol gruplarmız arasinda istatistiksel olarak bir anlamlılık saptanmamıştır. Trombosit agregasyon \% Amplitüd değerleri kontrol grubumuzda $\left(74,73 \pm 30,71^{\text {a }} \Omega\right)$, hasta grubu $\left(66,51 \pm 25,18^{\text {a }}\right.$ $\Omega$ )'na göre daha yüksek bulunmasına rağmen aralarında istatistiksel olarak bir anlamlılık gözlenmemiştir. Hem preeklemsi ve hem de KAH kontrol grubuna ait bireylerde trombosit agregasyon \% Amplitüd değerleri, hasta gruplarına göre daha yüksek olarak saptanmıştır. Sonuçta hem preeklemsi ve hem de KAH hasta-kontrol çalışmasının sonuçları benzer yönde tespit edilmiştir.

Yaptığımız literatür taramasında esansiyel hipertansiyonu olan 23 hasta ve 13 sağlıklı kontrol ile yapılmış bir araştırmada ADP ile indüklenmiş trombosit agregasyon değerleri incelendiğinde, eğim değerleri hasta grubunda $127,9 \pm 42,5 \Omega$, kontrol grubunda ise $118,3 \pm 38,1 \Omega$ olarak tespit edilmiştir (18). Yine aynı çalışmada hasta grubuna ait agregasyon \% Amplitüd değerleri 93,7 $\pm 14,3$ iken kontrol grubuna ait \% Amplitüd değeri 84,8 $\pm 21,3$ olarak saptanmıştır (18). Esansiyel hipertansiyon ile ilgili araştırmada hem eğim hem de \% amplitüd değerleri hasta grubunda kontrol grubuna kıyasla yüksek bulunmasına rağmen gruplar arasında istatistiksel olarak anlamlı bir farklılık gözlenmemiştir (18). Bizim çalışmamızda da esansiyel hipertansiyon çalışmasında olduğu gibi KAH hasta grubu eğim değerleri, kontrole göre yüksek olmasına rağmen istatistiksel olarak bir anlamlılık tespit edilmemiştir. Fakat yaptığımız çalış- mada elde ettiğimiz KAH \% Amplitüd değerleri, esansiyel hipertansiyon araştırmasındaki sonuçlarla uyuşmamaktadır. Yaptığımız çalışmada \% Amplitüd değerleri KAH kontrol grubunda, hasta grubuna göre daha yüksek olmasına rağmen gruplar arasında istatistiksel olarak bir anlamlılık yoktur.

Yapılan literatür taramasında koroner anjiyografi ile KAH olduğu saptan 43 kişilik bir çalışmada, hastalık şiddetine göre ADP aracılı trombosit agregasyon sonuçları değerlendirilmiş ve KAH alt grupları arasında istatistiksel olarak anlamlı bir farklılık bulunmamıştır (25). Bizler de yaptığımız bu çalışmada anjiyografi ile damar tıkanıklığı sayısı tespit edilen KAH olgularının, hastalık şiddetine göre trombosit fonksiyonlarının ne şekilde değiştiğini saptayabilmek için KAH olgularını 3 alt gruba ayırdık. Alt gruplarımızda hastalık şiddetine göre 1 damar, 2 damar ve 3 damarı tıkalı KAH hastalarının ve sağlıklı kontrollerin trombosit agregasyon eğim ve \% Amplitüd değerlerini karşılaştırdık. Hastalık şiddetine göre oluşturduğumuz alt gruplarda trombosit agregasyon eğim ve \% Amplitüd değerlerinde istatistiksel olarak herhangi bir anlamlılık tespit edilmemiştir. Çalışmamızın sonuçları yaptığımız literatür taraması ile uyumludur.

\section{SONUÇ}

Koroner anjiyografi ile damar tıkanıklığı sayısı belirlenen KAH olgularında, ADP aracılı agregasyon testi sonuçlarını hastalık şiddetine göre değerlendirdiğimiz bu çalışmada, damar tıkanıklığı sayısı ile agregasyon testi sonuçları arasında istatistiksel olarak anlamlı bir ilişki saptanmamıştır.

Hakem Değerlendirmesi: Dış bağımsız.

Peer Review: Externally peer-reviewed.

Etik Komite Onayı: Bu çalışma için etik komite onayı İstanbul Üniversitesi- Cerrahpaşa, Cerrahpaşa Tip Fakültesi Klinik Araştırmalar Etik Kurulu Etik Kurulu'ndan alınmıştır.

Ethics Committee Approval: Ethics committee approval for this study was received from the Ethics Committee of Istanbul University Cerrahpaşa, Cerrahpaşa Medical Faculty Clinical Research Ethics Committee. 
Bilgilendirilmiş Onam: Katılımcılardan bilgilendirilmiş onam alınmıştır.

Informed Consent: Written consent was obtained from the participants.

Yazar Katkıları: Çalışma Konsepti/Tasarım- T.U., G.A., B.İ., B.K.; Veri Toplama- B.K., G.A.; Veri Analizi/ Yorumlama- B.İ., B.K., A.D., G.K., M.G.; Yazı TaslağıG.A., G.K., A.D.; İçeriğin Eleştirel İncelemesi- T.U., M.G., B.K., B.İ.; Son Onay ve Sorumluluk- G.A., B.K., M.G., G.K., A.D., B.İ., T.U.

Author Contributions: Conception/Design of Study- T.U., G.A., B.I., B.K.; Data Acquisition- B.K., G.A.; Data Analysis/Interpretation- B.İ., B.K., A.D., G.K., M.G.; Drafting Manuscript- G.A., G.K., A.D.; Critical Revision of Manuscript- T.U., M.G., B.K., B.I.; Final Approval and Accountability- G.A., B.K., M.G., G.K., A.D., B.İ., T.U.

Çıkar Çatışması: Yazarlar çıkar çatışması beyan etmemişlerdir

Conflict of Interest: Authors declared no conflict of interest.

Finansal Destek: Bu çalışma İstanbul Üniversitesi Bilimsel Araştırma Projeleri Koordinasyon Birimi hibesi ile desteklenmiştir (Proje Numarası: T-7883/05072010).

Financial Disclosure: This work was supported by the grant of Scientific Research Projects Coordination Unit of Istanbul University (Project No: T-7883/05072010).

\section{KAYNAKLAR}

1. Timmis A, Townsend N, Gale C, Grobbee R, Maniadakis N, Flather M, et al. European Society of Cardiology: cardiovascular disease statistics 2017. Eur Heart J 2018;39(7):508-79.

2. Popa LE, Petresc B, Cătană C, Moldovanu CG, Feier DS, Lebovici A, et al. Association between cardiovascular risk factors and coronary artery disease assessed using CAD-RADS classification: a cross-sectional study in Romanian population. BMJ Open 2020;10(1):e031799.

3. Henein MY, Vancheri S, Bajraktari G, Vancheri F. Coronary Atherosclerosis Imaging. Diagnostics 2020;10(2):65.
4. Ulutin ON, Akman N, Ozcan E. Thrombosis, arteriosclerosis and hypercoagulability. Turk Tip Cemiy Mecm 1963;29:428-32.

5. Hamilos M, Petousis S, Parthenakis F. Interaction between platelets and endothelium: from pathophysiology to new therapeutic options. Cardiovasc Diagn Ther 2018;8(5):568-80.

6. Gawaz M, Borst O. The Role of Platelets in Atherothrombosis. In: Michelson A.D, Cattaneo M, Frelinger A, Newman P, editors. Platelets 4th edition. Massachusetts: USA 2019.p.459-67.

7. Totani L, Evangelista V. Platelet-leukocyte interactions in cardiovascular disease and beyond. Arterioscler Thromb Vasc Biol 2010;30(12):2357-61.

8. Weyrich AS, Zimmerman G.A. Platelets in Lung Biology. Ann Rev Physiol 2013;75:569-91.

9. Lefrançais E, Ortiz-Muñoz G, Caudrillier A, Mallavia B, Liu F, Sayah D.M, et al. The lung is a site of platelet biogenesis and a reservoir for haematopoietic progenitors. Nature 2017; 544(7648):105-09.

10. Ulutin ON. The platelets: Fundamentals and clinical applications. İstanbul: Kâğit ve Basim İsleri AŞ, 1976:ss.1-344.

11. Furie B, Furie BC, Flaumenhaft R. A journey with platelet P-selectin: the molecular basis of granule secretion, signalling and cell adhesion. Thrombosis Haemost 2001;86(07):214-21.

12. Bayram Gürel Ç, Ayaz G, Tuncel H, Kalkan T, Kurşun N, Ulutin T. Statik Manyetik Alanın Trombosit Agregasyonuna Etkisi. SABİAD 2020;3(3):173-8.

13. Vanhoutte PM. Endothelial dysfunction and coronary heart disease. Interaction of endothelium and thrombocytes. Schweiz Rundsch Med Prax 1993;82(42):1161-6.

14. Fuchs B, Budde U, Schulz A, Kessler CM, Fisseau C, Kannicht C. Flow-based measurements of von Willebrand factor (VWF) function: binding to collagen and platelet adhesion under physiological shear rate. Thromb Res 2010;125(3):239-45.

15. Selvadurai MV, Hamilton JR. Structure and function of the open canalicular system- 
the platelet's specialized internal membrane network. Platelets 2018;29(4):319-25.

16. Suzuki Y, Sano H, Mochizuki L, Honkura N, Urano T. Activated platelet-based inhibition of fibrinolysis via thrombin-activatable fibrinolysis inhibitor activation system. Blood Adv 2020;4(21):5501-11.

17. Güngör ZB, Ekmekçi H, Tüten A, Toprak S, Ayaz $\mathrm{G}$, Çalışkan $\mathrm{O}$, et al. Is there any relationship between adipocytokines and angiogenesis factors to address endothelial dysfunction and platelet aggregation in untreated patients with preeclampsia? Arch Gynecol Obstet 2017;296(3):495-502.

18. Ekmekçi H, Ekmekçi O.B, Erdine S, Sönmez $\mathrm{H}$, Ataev Y, Oztürk Z, et al. Effects of serum homocysteine and adiponectin levels on platelet aggregation in untreated patients with essential hypertension. J Thromb Thrombolysis 2009;28(4):418-24.

19. Sipahioglu NT, İlerigelen B, Gungor ZB, Ayaz G, Ekmekci H, Gurel ÇB, et al. Relation of biochemical parameters with flow-mediated dilatation in patients with metabolic syndrome. Chin Med J 2017;130(13):1564-9.
20. Tutluoglu B, Gurel ÇB, Ozdas SB, Musellim B, Erturan S, Anakkaya AN, et al. Platelet function and fibrinolytic activity in patients with bronchial asthma. Clin Appl Thromb Hemost 2005;11(1):77-81.

21. Tetik Ş, Koray AK. Kardiyovasküler hastalıklarda trombosit fonksiyon testleri: patofizyolojiden klinik yaklaşıma. Cumhuriyet Tip Derg 2010;32(2):264-74.

22. Born GVR. Aggregation of blood platelets by adenosine diphosphate and its reversal. Nature 1962;194:927-29.

23. Blanc JL, Mullier F, Vayne C, Lordkipanidzé M. Advances in platelet function testing light transmission aggregometry and beyond. J Clin Med 2020;9(8):2636.

24. Kaptan K. Trombosit Hastalıklarında Temel Tanısal Yaklaşım. İlk Basamak Kursu. Ankara 2006: p.1-5.

25. Ekmekci H, Isler I, Sonmez H, Gurel CB, Ciftci O, Ulutin T, et al. Comparison of platelet fibronectin, ADP-induced platelet aggregation and serum total nitric oxide (NOx) levels in angiographically determined coronary artery disease. Thromb Res 2006;117(3):249-54. 